\title{
Biological monitoring of occupational exposure to inorganic arsenic
}

\author{
P Apostoli, D Bartoli, L Alessio, J P Buchet
}

\begin{abstract}
Objectives-This study was undertaken to assess reliable biological indicators for monitoring the occupational exposure to inorganic arsenic (iAs), taking into account the possible confounding role of arsenicals present in food and of the element present in drinking water.
\end{abstract}

Methods-51 Glass workers exposed to As trioxide were monitored by measuring dust in the breathing zone, with personal air samplers. Urine samples at the end of work shift were analysed for biological monitoring. A control group of 39 subjects not exposed to As, and eight volunteers who drank water containing about $45 \mu \mathrm{g} / 1$ iAs for a week were also considered. Plasma mass spectrometry (ICP-MS) was used for the analysis of total As in air and urine samples, whereas the urinary As species (trivalent, $\mathrm{As}^{3}$; pentavalent, $\mathrm{As}^{5}$; monomethyl arsonic acid, MMA; dimethyl arsinic acid, DMA; arsenobetaine, AsB) were measured by liquid chromatography coupled with plasma mass spectrometry (HPLC-MS)

Results-Environmental concentrations of As in air varied widely (mean $84 \mu \mathrm{g} / \mathrm{m}^{3}$, SD 61, median 40) and also the sum of urinary iAs MMA and DMA, varied among the groups of exposed subjects (mean $106 \mu \mathrm{g} / 1$, SD 84, median 65). AsB was the most excreted species (34\% of total As) followed by DMA (28\%), MMA (26\%), and $\mathrm{As}^{3}+\mathrm{As}^{5}$ $(12 \%)$. In the volunteers who drank As in the water the excretion of MMA and DMA increased (from a median of 0.5 to $5 \mu \mathrm{g} / \mathrm{day}$ for MMA and from 4 to $13 \mu \mathrm{g} / \mathrm{day}$ for DMA). The best correlations between As in air and its urinary species were found for total iAs and $\mathrm{As}^{3}+\mathrm{As}^{5}$.

Conclusions-To avoid the effect of As from sources other than occupation on urinary species of the element, in particular on DMA, it is proposed that urinary $\mathrm{As}^{3}+\mathrm{As}^{5}$ may an indicator for monitoring the exposure to iAs. For concentrations of $10 \mu \mathrm{g} / \mathrm{m}^{3}$ the current environmental limit for iAs, the limit for urinary $\mathrm{As}^{3}+\mathrm{As}^{5}$ was calculated to be around $5 \mu \mathrm{g} / 1$, even if the wide variation of values needs critical evaluation and application of data. The choice of this indicator might be relevant also from a toxicological point of view. Trivalent arsenic is in fact the most active species and its measure in urine could be the best indicator of some critical effects of the element, such as cancer. (Occup Environ Med 1999;56:825-832)
Keywords: arsenic; speciation; biological monitoring

When assessing occupational exposure to inorganic arsenic (iAs) by biological monitoring, it is necessary to consider the biotransformation pathway of the element itself.

In the human body, iAs changes in oxidation state in both directions: pentavalent species can be found in the urine after a dose of the trivalent As and it has been shown that subjects who ingested meals rich in pentavalent As excreted mainly the trivalent species in urine. ${ }^{1}$ The reduction capacity of pentavalent As can be very efficient but results in increased toxicity: indeed, trivalent As has high affinity for thiol groups of proteins and molecules such as lipoic acid. $^{23}$

Biotransformation of arsenic, however, involves mainly methylation, ${ }^{4-8}$ leading to the formation and excretion of monomethylated and dimethylated compounds (monomethylarsonic acid, MMA; dimethylarsinic acid, DMA). Experimental and human observations suggest that two enzymatic activities with a different reaction rate are involved in this methylation. $^{9-12}$

Arsenobetaine (AsB) which represents, with tetramethylarsonium, the most important species of As in food does not undergo biotransformation and is almost completely eliminated through the urine: one single meal of seafood can induce, for example, a urinary excretion of total As of up to $1000 \mu \mathrm{g} / \mathrm{l}^{13-21}$

Other possible, quantitatively less important sources of As in biological media are smoking habits and air pollution of the general environment - for example, living in surroundings of some industrial settings such as non-ferrous foundries and glass factories. ${ }^{22-28}$

Drinking water may be a relevant source of iAs in some geographical areas, and this natural kind of water pollution has been related to skin alterations, cardiovascular diseases, and cancer. ${ }^{29-35}$

The absorption of As from food, water, and air explains the presence, in variable amounts, of the element in the urine of the general population. The urinary concentrations of As vary considerably, between 5 and $50 \mu \mathrm{g} / 1$, and therefore groups from different countries could be distinguished on this basis. The urinary As, for example is much higher in Japan and the United States than in European countries, where it varies. . $^{36-39}$

In occupationally exposed subjects, the urinary excretion of As metabolites varies in accordance to the dose absorbed from the working environment but may also be influenced by 
other sources among which food and water can play an important part.

After several years of biological monitoring of occupational exposure to As the measurement of some urinary species of the element (iAs itself, MMA, and DMA) has been suggested. The basic argument for justifying this choice is that these urinary As species are not influenced by the presence of organoarsenicals of dietary origin..$^{40-44}$

The correlation between As in ambient air and urinary As in exposed workers has been studied in several surveys with as biological indicator, usually the sum of these species of As. This correlation varied considerably, due to different working exposures investigated, different air sampling methods, and different analytical methods adopted both for environmental and biological samples s $^{38}{ }^{45-50}$ and to the possible confounding role of some methylated forms of dietary origin as recently emphasised. ${ }^{51}$

The aim of the present study is to investigate the relation between exposure to iAs and its species excreted in urine, to assess accurate biological indicators of exposure, considering the possible confounding contribution of arsenicals present in food and drinking water.

\section{Materials and methods}

OCCUPATIONALLY EXPOSED SUBJECTS

We examined 51 male workers employed in art glass manufacture and with different degrees of exposure to dust containing as the main toxic compound As trioxide. As documented in a previous paper, ${ }^{52}$ other elements were also present in airborne dusts but in the working conditions examined and for the concentrations measured they did not seem to influence the urinary excretion of As, when compared with other published data.

In the present investigation therefore we dealt with the study of the relation between the exposure to iAs and the excretion of total inorganic element and of its species.

The workers studied were 28 oven chargers, 10 batch mixers, and 13 moulders or finishers. The number of workers already investigated was increased by taking into consideration other people employed in the same tasks, performing environmental and biological monitoring by the same methods and carrying out the element speciation on all the urinary samples.

SUBJECTS DRINKING WATER CONTAINING AS

Eight healthy non-smoking men, 25-40 years old, who usually drank water with concentration of As $<1-2 \mu \mathrm{g} / 1$ were asked, for 1 week, to drink water coming from another municipal aqueduct and currently consumed by the general population living there. Water was collected once, at the beginning of the survey, in eight plastic 101 cans (one for each participant in the study). The As contained in the water was identified as iAs and the concentration of the element in different cans ranged between 42 and $46 \mu \mathrm{g} / \mathrm{l}$. This did not change between the beginning and at the end of investigation.
Table 1 Concentrations of arsenic in air $\left(\mu \mathrm{g} / \mathrm{m}^{3}\right)$

\begin{tabular}{llrrrl}
\hline & $n$ & Mean & \multicolumn{1}{c}{$S D$} & Median & Range \\
\hline Batch mixers & 10 & 59 & 56.4 & 26 & $10-154$ \\
Oven chargers & 28 & 127.0 & 89.4 & 123 & $10-312$ \\
$\begin{array}{l}\text { Moulders, } \\
\quad \text { finishers }\end{array}$ & 13 & 4.1 & 3.7 & 39 & $1.5-15$ \\
Total & 51 & 82.9 & 87.4 & 42 & $1.5-312$ \\
\hline
\end{tabular}

Each subject, was asked to drink 1-1.5 1/day of water and to avoid the consumption of meals rich in As, in particular, seafood.

Urine was collected during the entire day, its volume was measured, and a representative sample frozen at $-20^{\circ} \mathrm{C}$ until analysis.

The current procedures for informed consent were strictly applied.

CONTROL SUBJECTS

To ascertain the excretion of arsenic species in the general population, 39 men were assessed. They were not occupationally exposed to As, lived in areas not polluted by As from industrial plants, consumed drinking water with As concentrations $<1 \mu \mathrm{g} / 1$, and ate a diet poor in sea food.

The urine samples (second void) were collected in the morning and frozen at $-20^{\circ} \mathrm{C}$ until analysis.

ENVIRONMENTAL AND BIOLOGICAL MONITORING Environmental monitoring was conducted by collecting the airborne particulate matter in the breathing zone, on cellulose ester membranes by personal air samplers for a period of 6 hours on a normal working day, generally on Thursday. During environmental monitoring the workers did not regularly use respiratory masks.

For biological monitoring urine samples at the end of work shift were collected and frozen at $-20^{\circ} \mathrm{C}$ until analysis. All urine samples had a specific gravity ranging between 1018 and 1032 and therefore the urinary As concentrations were expressed as $\mu \mathrm{g} / 1$.

\section{ANALYSIS}

An inductively coupled plasma mass spectrometer (ICP-MS) ELAN 5000 (Perkin Elmer SCIEX), was used for the analysis of As in the environmental and urine samples, applying methods published elsewhere. ${ }^{9}$

The urinary As species were measured with liquid chromatography coupled with plasma mass spectrometry (MS-HPLC), with a weak anion exchange column and a mobile phase prepared with methanol ammonium dihydrogen phosphate, ammonium acetate, and glacial acetic acid. The measurement of single As species was carried out by standard additions.

The sensitivity of the method was $0.5 \mu \mathrm{g} / 1$ for the iAs, with a relative SD for environmental and biological determinations that ranged between $5 \%$ and $15 \%$, being higher for AsB, DMA, and MMA. For the single As species the sensitivities were: $\mathrm{As}^{3}$ and $\mathrm{As}^{5} 0.5 \mu \mathrm{g} / \mathrm{l}$; MMA 2 $\mu \mathrm{g} / 1$; DMA $1.5 \mu \mathrm{g} / 1$; and AsB $1 \mu \mathrm{g} / 1$. The recovery varied from $92 \%$ to $105 \%$. 
Table 2 Concentration of urinary As species in exposed and control subjects $(\mu g / l)$

\begin{tabular}{|c|c|c|}
\hline & $\begin{array}{l}\text { Workers } \\
\text { exposed to As }\end{array}$ & Controls \\
\hline $\mathrm{n}$ & 51 & 39 \\
\hline \multicolumn{3}{|l|}{$\mathrm{As}^{3}:$} \\
\hline Mean & 15 & $0.5^{\star}$ \\
\hline SD & 14 & 0.6 \\
\hline Geometric mean & 9 & 0.3 \\
\hline Median & 11 & 0.3 \\
\hline Range & $1-57$ & $\mathrm{nd}-1.2$ \\
\hline \multicolumn{3}{|l|}{$A s^{5}:$} \\
\hline Mean & 6 & - \\
\hline $\mathrm{SD}$ & 5 & - \\
\hline Geometric mean & 4 & - \\
\hline Median & 5 & - \\
\hline Range & $1-17$ & \\
\hline \multicolumn{3}{|l|}{$A s^{3}+\mathrm{As}^{5}:$} \\
\hline Mean & 20 & $0.5^{\star}$ \\
\hline SD & 18 & 0.6 \\
\hline Geometric mean & 11 & 0.3 \\
\hline Median & 14 & 0.3 \\
\hline Range & $1-68$ & $\mathrm{nd}-1.2$ \\
\hline \multicolumn{3}{|l|}{ MMA: } \\
\hline Mean & 30 & 1.2 \\
\hline $\mathrm{SD}$ & 29 & 1.1 \\
\hline Geometric mean & 16 & 0.6 \\
\hline Median & 18 & 0.9 \\
\hline Range & $1-95$ & $0.5-2.2$ \\
\hline \multicolumn{3}{|l|}{ DMA: } \\
\hline Mean & 58 & 6.8 \\
\hline SD & 50 & 4.0 \\
\hline Geometric mean & 42 & 5 \\
\hline Median & 36 & 5.2 \\
\hline Range & $10-232$ & $2.1-14.4$ \\
\hline \multicolumn{3}{|l|}{ AsBet: } \\
\hline Mean & 60 & 10.7 \\
\hline $\mathrm{SD}$ & 59 & 29.6 \\
\hline Geometric mean & 32 & 5.5 \\
\hline Median & 35 & 9.5 \\
\hline Range & n.d. -240 & $3-156$ \\
\hline \multicolumn{3}{|c|}{ Inorganic As+MMA+DMA: } \\
\hline Mean & 106 & 8.6 \\
\hline $\mathrm{SD}$ & 84 & 4.9 \\
\hline Geometric mean & 75 & 6 \\
\hline Median & 65 & 6.3 \\
\hline Range & $15-312$ & $2.5-22$ \\
\hline \multicolumn{3}{|l|}{ Total: } \\
\hline Mean & 166 & 19.3 \\
\hline $\mathrm{SD}$ & 107 & 81.4 \\
\hline Geometric mean & 127 & 15 \\
\hline Median & 140 & 10.6 \\
\hline Range & $10-361$ & $5-210$ \\
\hline
\end{tabular}

${ }^{\star}$ Measurable in 13 subjects.

nd=Non-detectable

QUALITY ASSURANCE AND STATISTICAL ANALYSIS The sum of As species analysed by the hyphenated method correlated well with As measured by a solvent extraction method and electrothermic atomisation-atomic absorbtion spectrometry analysis. ${ }^{53}$

The accuracy was evaluated with the standard reference material $2676 \mathrm{c}$ and $1643 \mathrm{c}$ of the National Institute of Standards and Technology (Gaithersburg, MD, USA) and for biological samples with control urine samples with assigned values of 40-60 and 123-185 $\mu \mathrm{g} / 1$ for As (Lyphocheck, BioRad).

The laboratory involved in analytical measurements adheres to the current quality assurance procedures and participates in the external quality programme organised by the Institute of Occupational Social and Environmental Medicine of the University of Erlangen, Nuremberg.

Statistical analysis of data was performed with Statgraphics software version 0.6, 1993. The normality of variable distribution was checked by the Kolmogorov test. The arithmetic mean (SD), geometric mean, median, and range are reported for non-normally distributed variables and a logarithmic transformation was used before correlation analysis, completed by $95 \%$ confidence intervals ( $95 \%$ CIs). Pearson correlation coefficients were calculated for all the variables. A multiple regression analysis was performed to analyse the relation between As in air and single species measured in urine. Given the strong correlation among the species, to minimise the multicollinearity we considered also the sum of $\mathrm{As}^{3}$ and $\mathrm{As}^{5}$. A selection of the predictors in the linear model was carried out by the mean of a bootstrap estimate of regression coefficients.

\section{Results}

Arsenic concentrations measured in air are reported in table 1 . The data were not normally distributed and varied widely in the entire group examined (mean 82.9, SD 87.4, median $42 \mu \mathrm{g} / \mathrm{m}^{3}$ ) and one subgroup in particular (moulders or finishers). The levels of exposure were higher in workers involved in handling the particulate matter (in oven chargers and some batch mixers). For 41 samples the values of iAs in air were higher than the current limit values (TLV-TWA) proposed by American Conference of Governmental Industrial Hygienists (ACGIH) $\left(10 \mu \mathrm{g} / \mathrm{m}^{3}\right)$. The corresponding limit from DFG is, however, much higher (100 $\left.\mu \mathrm{g} / \mathrm{m}^{3}\right)$.

The concentration of different urinary species $\left(\mathrm{As}^{3}, \mathrm{As}^{5}, \mathrm{MMA}, \mathrm{DMA}\right.$, and $\mathrm{AsB}$, ) in exposed workers and in the control group is reported in table 2 .

Also the urinary concentrations of As are not normally distributed and are widely variable. For 31 workers the sum of iAs, MMA, and DMA exceeded $50 \mu \mathrm{g} / \mathrm{g}$ creatinine, which is the biological exposure index suggested by ACGIH. ${ }^{40}$ It must be remembered that the

Table 3 Urinary excretion of As species in eight volunteers drinking water with arsenic ( $\mu g /$ day)

\begin{tabular}{|c|c|c|c|c|c|c|c|c|c|c|c|c|c|c|c|c|c|c|c|c|c|c|c|c|}
\hline & \multicolumn{6}{|c|}{$A s^{3}+A s^{5}$} & \multicolumn{6}{|l|}{$M M A$} & \multicolumn{6}{|l|}{$D M A$} & \multicolumn{6}{|l|}{$A s B$} \\
\hline & Mean & $S D$ & Median & $G M$ & Ran & & Mean & $S D$ & Median & $G M$ & Ran & & Mean & $S D$ & Median & $G M$ & Ran & & Mean & $S D$ & Median & $G M$ & Ran & \\
\hline \multirow{2}{*}{\multicolumn{25}{|c|}{$\begin{array}{l}\text { Baseline } \\
\text { Days of water intake: }\end{array}$}} \\
\hline & & & & & & & & & & & & & & & & & & & & & & & & \\
\hline 1 & 1.5 & 0.7 & 1.2 & 1.3 & 0.6 & 2.9 & 4.3 & 2.1 & 3.8 & 3.8 & 1.3 & 7.8 & 9.8 & 2.2 & 9.2 & 9.5 & 5.7 & 12.7 & 4.8 & 2.8 & 4.6 & 4.1 & 2 & 10 \\
\hline 2 & 1.4 & 0.6 & 1.5 & 1.3 & 0.6 & 2.6 & 5.4 & 2.3 & 4.6 & 5 & 2.8 & 10 & 12.5 & 3.7 & 12 & 12 & 7.7 & 18.1 & 2.9 & 0.5 & 2.7 & 2.9 & 2 & 4 \\
\hline 3 & 1.6 & 0.6 & 1.4 & 1.6 & 1.1 & 3.2 & 5.2 & 3.0 & 4.4 & 4.6 & 2.7 & 12.6 & 13.1 & 4.6 & 13.7 & 12.3 & 6.1 & 19.4 & 2.9 & 1.0 & 2.4 & 2.8 & 2 & 5 \\
\hline 4 & 1.2 & 0.7 & 1.0 & 1.1 & 2.2 & 5.2 & 3.6 & 0.8 & 3.4 & 3.5 & 0.4 & 2.8 & 11.0 & 2.4 & 10.9 & 10.7 & 6.6 & 14.2 & 1.4 & 1.1 & 1.3 & nd & nd & 3 \\
\hline $\begin{array}{l}1 \text { Day after the end } \\
\text { of water intake } \\
3 \text { Days after the end }\end{array}$ & 1.3 & 0.6 & 1.1 & 1.2 & 0.9 & 1.0 & 4.2 & 2.4 & 3.6 & 3.6 & 0.6 & 2.7 & 11.7 & 4.2 & 13.5 & 10.8 & 5.1 & 17.3 & 1.4 & 0.4 & 1.4 & 1.4 & 1 & 2.5 \\
\hline of water intake & 1.3 & 0.8 & 0.6 & nd & nd & 6.2 & 3.0 & 1.8 & 3.3 & nd & nd & 2.6 & 10.2 & 2.9 & 8.6 & 9.8 & 6.7 & 14.3 & 1.5 & 0.9 & 1.9 & nd & nd & 3 \\
\hline
\end{tabular}



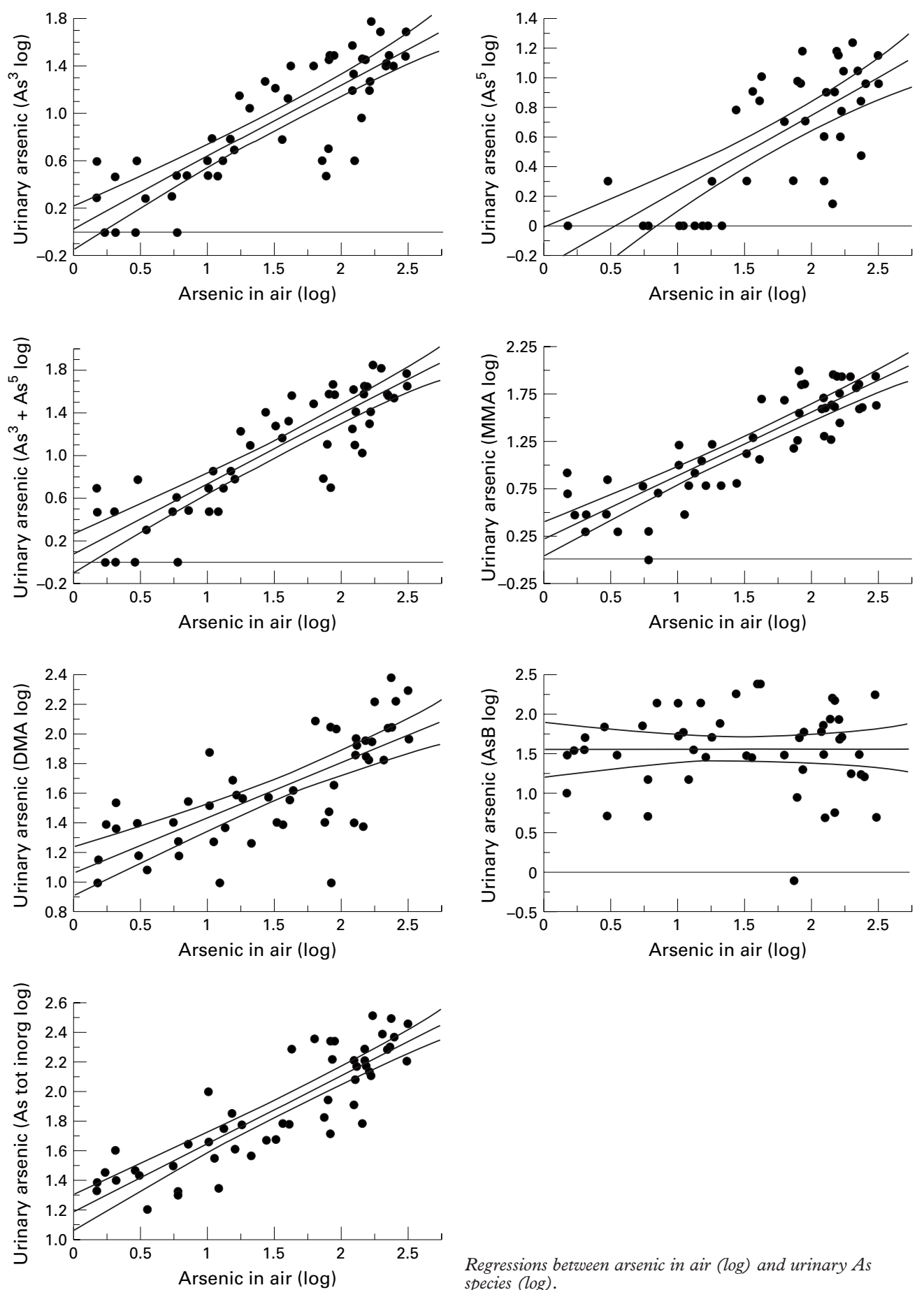

Regressions between arsenic in air (log) and urinary $A s$ species $(\log )$.

EKA value by DFG (for environmental concentration of As trioxide of $10 \mu \mathrm{g} / \mathrm{m}^{3}$ ) is the same,${ }^{41}$ while the tentative biological maximum permissible concentration for As, proposed by Lauwerys and Hoet is $30 \mu \mathrm{g} / \mathrm{g}$ creatinine. ${ }^{54}$ As our values are expressed in $\mu \mathrm{g} / 1$ and considering that creatinine for men is normally higher than $1 \mathrm{~g} / \mathrm{l}$, the exposure is probably overestimated.

The species excreted most was AsB, accounting for $34 \%$ of total As in exposed workers and $66 \%$ in the control group. Next was DMA, with $28 \%$ in workers and $36 \%$ in controls, and MMA with $21 \%$ and $26 \%$, respectively. Urinary iAs were around $11 \%$ of the total As excreted in workers but it was

measured only in 13 controls, in whom values were $0.5-1 \mu \mathrm{g} / 1$. This was greater than the value for all $\mathrm{As}^{3}$, and its presence and concentration in urine were probably due to variations in As metabolism (methylation capacity) of the small quantity of iAs ingested by the general population.

To verify the possible role as confounding factors of arsenic drunk in water the measurement of As species ( $\mu \mathrm{g} /$ day) was performed in volunteers who drank water with an As content of $42-46 \mu \mathrm{g} / \mathrm{l}$, and the results are reported in table 3. The species excreted most was DMA, whereas MMA showed a more rapid increase in urine (10 times the basal excretion). Due to 
Table 4 Equations of regression between inorganic As in air $(x)$ and urinary species of $A s(y)$

\begin{tabular}{lllll}
\hline Species & Equations $(\log )$ & $R$ & $R^{2}$ & $p$ Value \\
\hline $\mathrm{As}^{5}$ & $\mathrm{Y}=0.276+0.506 \mathrm{X}$ & 0.74 & 0.55 & 0.0001 \\
$\mathrm{As}^{3}$ & $\mathrm{Y}=0.048+0.599 \mathrm{X}$ & 0.83 & 0.69 & 0.0001 \\
$\mathrm{As}^{3+5}$ & $\mathrm{Y}=0.09+0.635 \mathrm{X}$ & 0.86 & 0.74 & 0.0001 \\
$\mathrm{MMA}$ & $\mathrm{Y}=0.221+0.655 \mathrm{X}$ & 0.86 & 0.75 & 0.0001 \\
DMA & $\mathrm{Y}=1.067+0.364 \mathrm{X}$ & 0.73 & 0.53 & 0.0001 \\
Arsenobetaine & $\mathrm{Y}=1.541+0.100 \mathrm{X}$ & 0.014 & 0.00 & 0.92 \\
iAs+MMA+DMA & $\mathrm{Y}=1.186+0.455 \mathrm{X}$ & 0.87 & 0.75 & 0.0001 \\
\hline
\end{tabular}

Table 5 Pearson correlation between As in air $(\log )(x)$ and different urinary As species (y)

\begin{tabular}{|c|c|c|c|c|c|c|c|}
\hline & $M M A$ & $D M A$ & $A s B$ & Air As & Total iAs* & $A s^{3}$ & $A s^{5}$ \\
\hline \multicolumn{8}{|l|}{ MMA: } \\
\hline Correlation & 1 & 0.65 & 0.06 & 0.71 & 0.86 & 0.83 & 0.72 \\
\hline $\mathrm{p}$ Value & 0 & 0.0001 & 0.6530 & 0.0001 & 0.0001 & 0.0001 & 0.0001 \\
\hline \multicolumn{8}{|l|}{ DMA: } \\
\hline Correlation & 0.65 & 1 & -0.10 & 0.78 & 0.9 & 0.68 & 0.42 \\
\hline p Value & 0.0001 & 0 & 0.5 & 0.0001 & 0.0001 & 0.0001 & 0.0063 \\
\hline \multicolumn{8}{|l|}{ AsB: } \\
\hline Correlation & 0.07 & -0.1 & 1 & -0.04 & -0.01 & 0.16 & 0.019 \\
\hline $\mathrm{p}$ Value & 0.6530 & 0.5009 & 0 & 0.7852 & 0.9697 & 0.2676 & 0.9072 \\
\hline \multicolumn{8}{|l|}{ As in air: } \\
\hline Correlation & 0.71 & 0.78 & -0.04 & 1 & 0.79 & 0.75 & 0.59 \\
\hline p Value & 0.0001 & 0.0001 & 0.7852 & 0 & 0.0001 & 0.0001 & 0.0001 \\
\hline \multicolumn{8}{|c|}{ Total inorganic As: ${ }^{\star}$} \\
\hline Correlation & 0.86 & 0.9 & -0.01 & 0.79 & 1 & 0.86 & 0.64 \\
\hline $\mathrm{p}$ Value & 0.0001 & 0.0001 & 0.9697 & 0.0001 & 0 & 0.0001 & 0.0001 \\
\hline \multicolumn{8}{|l|}{$\mathrm{As}^{3}:$} \\
\hline Correlation & 0.83 & 0.68 & 0.16 & 0.75 & 0.86 & 1 & 0.67 \\
\hline p Value & 0.0001 & 0.0001 & 0.2676 & 0.0001 & 0.0001 & 0 & 0.0001 \\
\hline \multicolumn{8}{|l|}{$A s^{5}:$} \\
\hline Correlation & 0.72 & 0.42 & 0.02 & 0.59 & 0.64 & 0.67 & 1 \\
\hline $\mathrm{p}$ Value & 0.0001 & 0.0063 & 0.9072 & 0.0001 & 0.0001 & 0.0001 & 0 \\
\hline
\end{tabular}

$\star$ Total iAs $=\mathrm{As}^{3}+\mathrm{As}^{5}+\mathrm{MMA}+\mathrm{DMA}$.

Table 6 Bootstrap variable selection

\begin{tabular}{llllll}
\hline Step & Variable & $R^{2}$ & $C(p)$ & $F$ & Probability $>F$ \\
\hline 1 & Total iAs & 0.7347 & 4.423 & 107.98 & 0.001 \\
2 & As $^{3}+^{5}$ & 0.035 & 0.953 & 5.78 & 0.01 \\
\hline
\end{tabular}

Total iAs=sum of $\mathrm{As}^{3}+\mathrm{As}^{5}+\mathrm{MMA}+\mathrm{DMA}$.

the dietary regimen, required by survey protocol, which limited food rich in As, AsB gradually decreased. Trivalent As, in concentrations of 1-2 $\mu \mathrm{g}$ /day was measured in three people. The excretion of different species decreases between 19\% (iAs) and 42\% (MMA) after the end of drinking the water high in As.

We also found that the biological markers related to As drunk in water varied greatly probably as a result of different methylation capacities of different people.

The regressions between As in air and urinary species of As measured in exposed glass workers are shown in the figure and the related equations in table 4 . In table 5 the Pearson correlation coefficients (covariance and $\mathrm{p}$ value) are reported. All the urinary As species, AsB excluded, correlated well with As in air. The $R$ values ranged between 0.87 and 0.73 and covariance between 0.59 and 0.79 .

The bootstrap variable selection (table 6) shows that iAs+MMA+DMA and $\mathrm{As}^{3}+\mathrm{As}^{5}$ were best correlated with concentrations of As in air.

\section{Discussion}

Mammals excrete the iAs in urine as methylated metabolites and partially as trivalent or pentavalent species. As the excretion rate is closely related to the metabolic capacity of the organism clear cut differences are found between animal species. ${ }^{55}$
Buchet et $a l^{11}$ showed in humans a mean excretion in 4 days of $45 \%$ of a single dose of $500 \mu \mathrm{g}$ trivalent As administered through drinking water, whereas Pomroy et $a \bar{l}^{6}$ found urinary excretion of around $38 \%$ of As drunk during 48 hours by volunteers who ingested $\mathrm{As}^{5}$.

After ingestion of a dose of iAs, part of the dose is methylated into MMA and DMA but a considerable proportion is excreted without transformation. During the two consecutive 24 hour periods after the ingestion of $500 \mu \mathrm{g} \mathrm{As}$, $8 \%$ and $2.3 \%, 5.3 \%$ and $2.3 \%, 9.3 \%$ and $8.5 \%$ of the dose were eliminated in urine as iAs, MMA, and DMA, respectively. ${ }^{11}$

Similar proportions of iAs $(15 \%$ of total As excreted in urine) have been found in urine of people consuming drinking water contaminated with As. ${ }^{31}$

A more efficient methylation for low doses of As may be hypothesised on the basis of observations related to possible inhibition of DMA formation after high As doses in humans ${ }^{57}$ and in rats. ${ }^{12}$

Organoarsenical compounds are excreted in urine at a higher rate than the inorganic forms. This is particularly the case with As from seafood. As an example, Brown et $a l^{58}$ gave a small dose of radiolabelled AsB to six volunteers and found an excretion of $67 \%$ of the dose within 24 hours and of $>98 \%$ within 24 days.

A more recent investigation ${ }^{51}$ failed to show a biologically significant absorption of iAs either present as such in the food or formed from organoarsenicals during cooking or digestion.

The measurement of As in urine may therefore be regarded as the most reliable indicator of recent exposure to iAs from drinking water, and around $60 \%-75 \%$ of ingested As is excreted by urine. ${ }^{12} 363955$

The results of our study indicate that ingestion of drinking water in which the concentration of iAs was around $45 \mu \mathrm{g} / 1$ even for a short period can rapidly induce excretion of high amounts of element, with a progressive increase of methylated species of As (MMA and DMA). The percentage of total As excreted was around $50 \%$ of ingested As and the increase from basal values was higher for iAs and MMA (from 0.06 to 1.6 and from 0.4 to $5.2 \mu \mathrm{g} \mathrm{As} / 1$, respectively), even though DMA remains the most excreted species $(50 \%$ of total As). Overall, there was no evidence of a ceiling in methylation capacity even though a wide difference between people was shown, due to the fact, for example, that $\mathrm{As}^{3}$ was not measurable in some people before and after the end of drinking the water high in As. The absorption of As through drinking water does not seem to modify the pattern of excretion of urinary metabolites of As.

The MMA:DMA ratio ranging from 0.3 to 0.4 proved to be similar to published values, whereas lower ratios $(0.1-0.2)$ were found by Hopenhayn et al. ${ }^{8}$ In that survey the concentrations of As in drinking water were much higher $(<680 \mu \mathrm{g} / \mathrm{l})$ and the corresponding mean of urinary As concentrations varied from 60 to $580 \mu \mathrm{g} / \mathrm{l}$, with percentages of iAs from $14 \%$ to 
Table 7 Comparison between species percentage (calculated on As concentration) in urine from present study and two other investigation

\begin{tabular}{llllll}
\hline & $A s^{3 \%}$ & $A s^{5 \%}$ & $M M A \%$ & $D M A \%$ & $\begin{array}{l}\text { Total } A s^{\star} \\
\text { (range) } \mu g / l\end{array}$ \\
\hline Present study & 15 & 5 & 25 & 55 & $10-390$ \\
Farmer and Johnson $1990^{45}$ & 11 & 3 & 18 & 69 & $27-517 \dagger$ \\
Offergelt et al $1992^{50}$ & 26 & & 11 & 57 & $65-117^{\star}$ \\
\hline
\end{tabular}

*Inorganic As+MMA+DMA

$+\mu \mathrm{g} / \mathrm{g}$ creatinine.

$18 \%$. The authors stated that the main differences found for MMA:DMA were due to exposure, smoking, residence, and ethnicity, and together these variables explained about $30 \%$ of the variability in MMA:DMA.

The importance to health of ingestion of iAs from water is estimated by some authors to be a risk of cancer, which, for water containing 50 $\mu \mathrm{g}$ iAs $/ 1$, is comparable with environmental tobacco smoke and radon in homes. ${ }^{59} \mathrm{~A}$ reduction of the currently accepted limit of $50 \mu \mathrm{g} / 1$ for As in drinking water, which is able to cause measurable amounts of iAs in urine, was therefore recommended. ${ }^{23} 3639$

For occupational exposure, as previously recalled several studies attempted to assess the relation between occupational exposure to As and the urinary excretion of its metabolites in different industrial settings: the urinary concentrations of arsenic calculated for exposure to $50 \mu \mathrm{g} / \mathrm{m}^{3}$ of the element varied from 78 to $220 \mu \mathrm{g} / \mathrm{l}^{40}$

The discrepancy among surveys may be explained by some variable factors, such as the different methods of environmental monitoring, or the collection of urine samples, or even the different analytical methods for urinary As and its species.

In accordance with some authors, ${ }^{46}{ }^{60}$ we also found an influence on the amount of As inhalation due to the use of respirators, the role of hand contamination, and oral ingestion in As sometimes relevant in workplaces such as glass manufacturing and metal smelting.

Considering the quality of analytical methods, problems may arise from lack of standardisation of analytical procedures (mainly for the As speciation in urine), from the absence of certified material, and from the difficulty in planning quality control programmes.

Different estimates of urinary As may, however, be due to the characteristics of urinary biomarkers. Individual metabolic capacity affects metabolism, by oxidation, reduction, and methylation of an element and so affects the presence of different metabolites. Furthermore, sources other than occupational may have a relevant influence. As previously seen, the absorption of arseno-organic compounds through seafood can modify the urinary excretion of As, due to AsB and probably DMA. The DMA does not appear as the methylation product of iAs in seafood, but rather as a product of organoarsenical catabolism. ${ }^{6162}$

Buchet et $a l^{51}$ concluded that in occupational exposure the sum of iAs, MMA, and DMA can be misleading for biological monitoring, as when urine samples are collected even 2 days after a meal containing As in seafood the unmetabolised form of the element can be measured.

The measurement of the urinary excretion of iAs, MMA, and especially DMA for biological monitoring of exposure to iAs could therefore be revised to avoid the possibly confounding effect of consumption of As in seafood from other sources.

Our data are similar to those from other investigations in which As speciation was carried out (table 7). Farmer in particular, ${ }^{45}$ measured $\mathrm{As}^{5}, \mathrm{As}^{3}, \mathrm{MMA}$, and DMA in urine from workers engaged in the electronics industry, wood preservation, glass works, and synthesis of arsenicals. The means of the urinary As metabolites were <10, 49.9, 79.4, and $245 \mu \mathrm{g} / \mathrm{g}$ creatinine, respectively. For the most exposed groups, the means of single As species were $1 \%-6 \%$ for $\mathrm{As}^{5}, 11 \%-14 \%$ for $\mathrm{As}^{3}, 14 \%-18 \%$ for MMA, and $63 \%-70 \%$ for DMA.

This evidence is similar to that of our present investigation. In our case the oxidation to $\mathrm{As}^{5}$ was evident only for higher concentrations of As in air, as $\mathrm{As}^{5}$ was not detectable by our ICP and HPLC-MS method for 10 workers in the group at lower exposure. This suggests that the oxidation of $\mathrm{As}^{3}$ into $\mathrm{As}^{5}$ might be related to absorbed As dose.

Finnish authors ${ }^{63}$ suggested a biological monitoring method involving only the measurement of iAs: they found that a urinary excretion of $5 \mu \mathrm{g}$ iAs/ 1 could be expected after an $8 \mathrm{~h}$ exposure to $10 \mu \mathrm{g} \mathrm{As} / \mathrm{m}^{3}$.

From our present investigation when the exposure concentration is $10 \mu \mathrm{g} / \mathrm{m}^{3}$, the following concentrations of urinary As species are to be expected :

$\mathrm{As}^{3}, 4.3 \mu \mathrm{g} / \mathrm{l} ; \mathrm{As}^{3}+\mathrm{As}^{5}, 5.3 \mu \mathrm{g} / \mathrm{l} ; \mathrm{MMA}, 7.5$ $\mu \mathrm{g} / 1$; DMA, $26.9 \mu \mathrm{g} / 1$; sum of iAs, MMA, DMA, $43.7 \mu \mathrm{g} / 1$.

The variability of the data already mentioned, mainly for low values of iAs in air suggests, however, that evaluation and application of these data should be cautious.

As well as considerations about correlation between air As and urinary As species, the significance of measurement of the iAs species in urine must also be emphasised. From a toxicological point of view, trivalent As is the most critical species, due to both its reactivity with thiol groups and its easy diffusion through biological membranes. ${ }^{2}$ When exposure increases, an increase of iAs in tissues and urine would be expected, as a consequence of the progressive saturation of methylation capability. It has been postulated that a decreased $\mathrm{As}^{3}$ methylation might be related to the appearance of effects of As - such as cancer-given that methylation is considered to be a detoxifying mechanism. ${ }^{64} 65$

In our experience, however, only severe acute intoxications by iAs (suicide attempt or acute arsine intoxication, for example) can lead to complete saturation of metabolic capability, and this occurrence can hardly happen in usual, even bad, occupational exposure situations.

Also, Hopenhayn et at did not find a saturation of methylation in subjects who drank water with a high concentration of As. 
However, because methylation reactions are never fully efficient (a small iAs is always excreted in urine as well as MMA and DMA), a competition must exist for As between the body binding sites, including methyltransferases and many proteins. Critical sites-for example, for cancer development-may be protected by many other less critical sites. These are progressively occupied in cases of chronic absorption, "opening" the access to the most critical sites. According to this hypothesis methylation reactions allow $\mathrm{As}^{3}$ binding sites to be cleared by formation of MMA and DMA with lower affinity for binding sites.

Nevertheless, it seems that during formation of MMA and DMA $\left(\mathrm{As}^{5}\right)$, trivalent methylated As can be formed and impair the cellular response to oxidation. ${ }^{66}$ Another point worth stressing is that differences in methylating capacity are probably due to methyltransferase gene polymorphism as suggested by Vahter et $a l .^{33}$ Inorganic As in urine could, therefore, be more closely related to the most critical effect (cancer) than other biological indicators of the element.

A limiting factor for the choice of iAs as an indicator for routine biological monitoring of occupational exposure to As is that the analytical method for iAs is more difficult because of the lower concentration of iAs to be measured and the complexity of procedures to separate it.

1 Yamauchi H, Yamamura Y. Dynamic change of inorganic arsenic and methylarsenic compounds in human urine after oral intake as arsenic trioxide. Ind Health 1979;17:79-83.

2 Buchet JP, Lauwerys R. Study of factors influencing the in vivo methylation of inorganic arsenic. Toxicol Appl Pharmacol 1987;91:65-74.

Buchet JP, Lauwerys R. Role of thiols in the in vitro methylation of inorganic arsenic by rat liver cytosol. Biochem Pharmacol 1988;37:3149-53.

4 Crecelius E. Changes in the chemical speciation of arsenic following ingestion by man. Environ Health Perspect 1977;19:147-50.

5 Costello RJ, Eller PM, Hull RD. Measurement of multiple inorganic arsenic species. Am Ind Hyg Assoc f 1983;44:21-8.

6 Vahter M, Marafante E, Dencker L. Metabolism of arsenobetaine in mice, rats and rabbits. Sci Total Environ 1983;30: 197-211.

7 Marafante E, Vahter M, Norin H, et al. Biotransformation of Marafante $\mathrm{E}$, Vahter $\mathrm{M}$, Norin $\mathrm{H}$, et al. Biotransformation of
dimethylarsinic acid in mouse, hamster and man. $\mathcal{J} A p p l$ dimethylarsinic acid in

8 Hopenhayn-Rich C, Smith AH, Goeden HM. Human studies do not support the methylation thereshold hypothesis for the toxicity of inorganic arsenic. Environ Res 1993;60: 161-77.

9 Apostoli P, Alessio L, Romeo L, et al. Metabolism of arsenic after acute occupational arsine intoxication. F Toxicol Environ Health 1997;52:331-42.

10 Biggs M, Rich C, Smith AH, et al. Methylation study of a population environmentally exposed to arsenic in drinking water. Environ Health Perspect 1996;104:620-8.

11 Buchet JP, Lauwerys R, Roels H. Comparison of the urinary excretion of arsenic metabolites after a single oral dose of sodium arsenite, monomethylarsonate, or dimethylarsinate in man. Int Arch Occup Environ Health 1981;48:71-9.

12 Buchet JP, Lauwerys R. Study of inorganic arsenic methylation by rat liver in vitro: relevance for the interpretation of tion by rat liver in vitro: relevance for the interpretat

13 Lunde G. Occurrence and transformation of arsenic in the marine environment. Environ Health Perspect 1985;19:47-52.

14 Lovell MA, Hisanage A, Farmer JG. Arsenic speciation in urine from humans intoxicated by inorganic arsenic compounds. Hum Toxicol 1985;4:203-14

15 Mohrita T, Hisanage A, Ishinishi M. Arsenic intake and excretion by Japanese adults. Food Chem Toxicol 1990;28 521-9.

16 Phillips DJ. As in aquatic organisms: a review, emphasizing chemical speciation. Acquatic Toxicology 1990;16:151-86.

17 Tam GKH, Charbonneau SM, Bryce F, et al. Excretion of a single oral dose of fish-As in man. Bull Environ Contam Toxicol 1982;28:669-73.

18 Kaise T, Watanabe S, Itoh $\mathrm{K}$. The acute toxicity of arsenobetaine. Chemosphere 1985;9:1327-32.

19 Hanaoka K, Koga H, Tagawa H, et al. Degradation of arsenobetaine to Asi by the microorganisms occuring in the nobetaine to Asi by the microorganisms occuring in the
suspended substances. Comp Biochem Physiol B Biochen Mol Biol 1992;101:595-9.
20 Borum DR, Abernathy CO. Human oral exposure to inorganic arsenic. Environ Geochem Health 1994;16:21-9.

21 Vaessen HA, Van Ooik A. Speciation of arsenic in Dutch total diets: methodology and results. $Z$ Lebensm Unters For sch 1989;189:232-5

22 Holland RH, Wilson RH, Acevedo AR. The cigarette smoke arsenic cancer of the lung problem. Acta-Unio Internationalis Contra Cancerum 1959;15:608-11.

23 International Agency for Research on Cancer. Arsenic and arsenic compounds. In: IARC monographs on the evaluation of the carcinogenic risk of chemicals to man. Vol 23. Some metals and metallic compounds. Lyons: IARC, 1980:39-141.

24 US Environmental Protection Agency. Health assessment document for inorganic arsenic. Final report. Research Triangle Park, NC: US EPA, Environmental Criteria and Triangle Park, NC: US EPA, Environmental

25 Pershagen G. Lung cancer mortality among men living near an arsenic-emitting smelter. Am F Epidemiol 1985;122:68494.

26 Plissar L, Lowry-Coble K, Kalman DA, et al. Pathways of human exposure to arsenic in a community surrounding a copper smelter. Environ Res 1990;53:29-47.

27 Buchet JP, Staessen J, Roels H, et al. Geographical and temporal differences in the urinary excretion of inorganic arsenic: a Belgian population study. Occup Environ Med 1996;53:320-7.

28 Vangronsveld J, Van Assche F, Clijsters H. Reclamation of a base industrial area contaminated by non-ferrous metal: in situ metal immobilization and revegetation. Environmental Pollution 1995;87:51-9.

29 Wu MM, Kuo TL, Hawang YH, et al. Dose response relation between arsenic concentration in well water and mortality from cancers and vascular diseases. $\mathrm{Am} \mathcal{F}$ Epidemiol 1989;130:1123-32.

30 Chen CJ, Wang CJ. Ecological correlation between aesenic level in well water and age-adjusted mortality from malignant neoplasms. Cancer Res 1990;50:5470-4.

31 Del Razo LM, Hernandez JL, Garcia-Vargas GG, et al. Urinary excretion of arsenic species in a human population chronically exposed to arsenic via drinking water. A pilot chronically exposed to arsenic via drinking water. A pilot
study, Environmental Geochemistry and Health 1994;16:91study,

32 Hopenhayn-Rich C, Biggs LM, Smith H, et al. Methylation study of a population environmentally exposed to arsenic in drinking water. Environ Health Perspect 1996;104:620.

33 Vahter M, Concha G, Nermell B, et al. A unique metabolism of inorganic arsenic in native Andean women. Eur f Pharmacol 1995;293:455-62.

34 Bates MN, Smith AH, Hopenhayn-Rich C. Arsenic ingestion and internal cancers: a review. Am f Epidemiol 1992;135:462-76.

35 Borgono JM, Vincent $\mathrm{P}$, Venturino $\mathrm{H}$, et al. Arsenic in the drinking water of the city of Antofagasta: epidemiological anc clinical study before and after the installation of a treatment plant. Environ Health Perspect 1997;19:103-5.

36 US Environmental Protection Agency. Special report on ingested inorganic arsenic: skin cancers nutritional essentiality. Washington, DC: US EPA, 1988. (EPA 625/3-87/013.)

37 Yamauchi H, Takahashi K, Mashiko M, et al. Biological monitoring of arsenic exposure of gallium arsenide and arsenic exposed workers by determination of inorganic arsenic and its metabolites in urine and hair. Am Ind Hyg Assoc f 1989;50:606-12.

38 Smith TJ, Crecelius EA, Reading JC. Aiborne arsenic exposure and excretion of methylated arsenic compounds. Environ Health Perspect 1977; 19:89-93.

39 Agency for toxic substances and diseases registry. Toxicological profile for arsenic update. Atlanta, Georgia: ATSDR, 1993. (Report TP 92/102.)

40 American Conference of Governmental Industrial Hygienists. Documentation of biological exposure index: arsenic, suppl. Cincinnati, OH: ACGIH, 1996.

$41 D F G$ List of MAK and BAT values 1997. Weinheim: Wiley-VCH Verlag $\mathrm{GmbH}, 1997$

42 Foà V, Colombi A, Maroni M, et al. The speciation of the chemical forms of arsenic in the biological monitoring of exposure to inorganic arsenic. Sci Total Environ 1984;34: 241-59

43 Foà V, Colombi A, Maroni M, et al. Arsenic in biological indicators for the assessment of human exposure to industrial chemicals 1987. Luxembourg: Commission of the European Communities, 1987.

44 Aizawa Y, Takata T. Biological monitoring of arsenic exposure. In: Fiserova-Bergerova V, Ogata M, eds. Biological monitoring of exposure to industrial chemicals, pp. 91-94. monitoring of exposure to industrial chemicals, pp. 91-94. Industrial Hygienists, 1990

45 Farmer JG, Johnson LR. Assessment of occupational exposure to inorganic arsenic based on urinary concentratio and speciation of arsenic. Br F Ind Med 1990;47:342-8.

46 Vahter M, Friberg L, Rahnster B, et al. Airborne arsenic and urinary excretion of metabolites of inorganic arsenic among smelter workers. Int Arch Occup Environ Health 1986;57:79-91

47 Landrigan PJ, Costello RJ, Stringer WT. Occupational exposure to arsine. An epidemiologic reappraisal of current standards. Scand $\mathcal{f}$ Work Environ Health 1982;8:169-77.

48 Enterline P, Henderson VL, Marsh GM. Exposure to arsenic and respiratory cancer: a reanalysis. Am $\mathcal{f}$ Epidemiol 1987;125:929-38.

49 Pinto SS, Varner MO, Nelson KW, et al. Arsenic trioxide absorption and excretion in industry. 7 Occup Med 1976;18:677-80. 
50 Offergelt JA, Roels H, Buchet JP, et al. Relation between airborne trioxide and urinary excretion of inorganic arsenic
and its methylated metabolites. Br f Ind Med 1992;49:387and i.

51 Buchet JP, Lison D, Ruggeri M, et al. Assessment of exposure to inorganic arsenic, a human carcinogen, due to the consumption of seafood. Arch Toxicol 1996;70: $773-8$

52 Apostoli P, Giusti S, Bartoli D, et al. Multiple exposure to arsenic, antimony and other elements in art glass manufacturing. Am F Ind Med 1998;34:65-72.

53 Bavazzano P, Perico A, Rosendahl K, et al. Determination of As by solvent extraction and ETA AS. Fournal of Atomic Absorbtion Spectrometry 1996;11:521-24.

54 Lauwerys RR, Hoet P. Industrial chemical exposure guidelines for biological monitoring, 2nd ed. Boca Raton: Lewis, 1993.

55 Vahter M. Species differences in the metabolism of arsenic. Environmental Geochemistry and Health 1994;16:171-9.

56 Pomroy C, Charbonneau SM, McCullough RS, et al. Pomroy C, Charbonneau SM, McCullough RS, et al. Human retention

57 Mahieu P, Buchet JP, Roels H, et al. The metabolism of arsenic in humans acutely intoxicated by As203. Its significance for the duration of BAL. Therapy Clinical Toxicology 1981;18:1067-75.

58 Brown LM, Pottern LM, Blot WJ. Lung cancer in relation to environmental pollutants emitted from industrial sources. Environ Res 1984;34:250-61.
59 Smith AH, Hopenhayn Rich C, Bates MN, et al. Cancer risks from arsenic in drinking water. Environ Health Perspect 1992;97:259-67.

60 Roels H, Buchet JP, Truc J, et al. The possible role of direct ingestion on the overall absorption of cadmium or arsenic in workers exposed to $\mathrm{CdO}$ or $\mathrm{As} 2 \mathrm{O} 3$ dust. Am 7 Ind Med 1982;3:53-65.

61 Le XC, Cullen WR, Reimer KJ. Human urinary arsenic excretion after one time ingestion of seaweed, crab and shrimp. Clin Chem 1994;40:617-24.

62 Ma MS, Le XC. Effect of arsenosugar ingestion on urinary arsenic speciation. Clin Chem 1998;44:539-50.

63 Hakala E, Pyy L. Assessment of exposure to inorganic arsenic by determining the arsenic species excreted in urine. Toxicol Lett 1995;77:249-58.

64 Carlson-Lynch H, Beck BD, Boardman PD. Arsenic risk assessment. Environ Health Perspect 1994;102:354-6.

65 Marcus WL, Rispin AS. Threshold carcinogenicity using arsenic as an example. In: Cothern CR, Mehlman MA, Marcus WL, eds. Advances in modern environmental toxicology risk assessment and risk management of industrial and environmental chemical. Princeton, NJ: Princeton Scientific, 1988:133-58.

66 Styblo M, Serves SV, Cullen WR, et al. Comparative inhibition of yeast glutathiione reductase by arsenicals and arsenothiols. Chem Res Toxicol 1997;10:27-33.

\section{Rejected manuscripts}

From February 1994, authors whose submitted articles are rejected will be advised of the decision and one copy of the article, together with any reviewer's comments, will be returned to them. The fournal will destroy remaining copies of the article but correspondence and reviewers' comments will be kept. 